\title{
IMPACT OF WEIRS ON FISH FAUNA OF WAK-OYA, A TRIBUTORY OF THE KELANI RIVER
}

\author{
A.B. KOTALAWALA \\ Department of Zoology, University of Sri Jayewarderiapura, Nugegoda.
}

(Date of receipt : 23 February 1993)
(Date of acceptance $:$ 18 December 1993)

\begin{abstract}
Wak-oya is a tributary of the Kelani River originating in the rain forests of Southwestern Icthyological Province of Sri Lanka. It is impounded by toro weirs constructed to form reservoirs to supply water to the city of Colombo. This tributary was studied from the upper feeding canals to the lower end near the river from January 1990 to August 1992 to obtain information on the physico-chemical and biological status prevailing in the stream. This study revealed that the changes in normal variation pattem of some chemical parameters near the weirs and the rubber factory is mainly due to the release of effuents into the stream. The natural downstream pattern of species composition, abundance, diversity and spawning migration of fish is disturbed by the weirs, gem mining on the stream bed and the chemical contamination of stream water. Despite the disturbed conditions Wak oya supports twenty eight species of fish of which four are endangered and endemic to Sri Lanka. Out of sixteen cyprinids found in the stream, three are dominant and found in all habitats.
\end{abstract}

Key words: Diversity, fish species, flow regime, Kelani river, spaming migration, Wak-oya, weirs

\section{INTRODUCTION}

Impounding rivers and streams for supplying water to cities, agriculture and generation of hydro-electric power is common in many countries. This alters habitats so that neither the reservoirs nor the tailwaters provide suitable conditions for native fish fauna. The studies on postimpoundment effects of Tennessee River of United States reported that after the construction of dams half of the species of native fish fauna, many of them cyprinids were, eliminated from the river. ${ }^{1}$ In the newly formed Itezhi-tezhi lake of Zambia, marked changes of community structure was reported after dam construction. The most obvious was the decline of species diversity and the shift in species composition from a community with a preponderance of riverine Alestes lateralis (Boulenger) (Characidae) to one dominated by cichlids. ${ }^{2}$ The pre and post-impoundment studies of the Cow Green Reservoir of England showed that the length-for-age and fecundity of fish species that live in the inundated region decreased. ${ }^{3}$

In Sri Lanka, the impoundment of rivers and streams for agriculture and for hydro-electric power generation is common. One of the main multipurpose projects is the Accelerated Mahaweli Project. This comprises a series of dams constructed across the Mahaweli River with water diverted to the arid North-Central Province through channels. As a result the downstream flow along the main channels of the river has been reduced and this has affected fish species such as Labeo fisheri (Jorden \& Stark) which prefer deeper pools in fast flowing streams. ${ }^{4}$ According to 
the Kalu Ganga multi purpose project prefeasibility report, there are about seven species of migratory barbs in this area which migrate to feeding canals for spawning. Life cycles of these fishes have been affected by the construction of dams. ${ }^{5}$

The ecology and fish production of major reservoirs of Sri Lanka have been fairly well studied. 6-9 However ecological surveys of streams are rare. ${ }^{10-12}$ Although impoundment of rivers and streams has been taking place for more than 100 years in the country, pre and post-impoundment studies are very rare. The prefeasibility survey of Kaluganga Project has shown that the fish fauna of the river, mainly the endemic and endangered species could be affected by the impoundments. ${ }^{5}$ The Wak-oya, which supports a number of endemic and endangered species, has not been studied before or after the impoundment. The aim of the present study was to obtain information on the present physico-chemical and biological status prevailing in Wak oya after the impoundment.

\section{METHODS AND MATERIALS}

The study area is shown in Figure 1. Kalatuwawa ela joins Wak oya at Labugama and flows for $14 \mathrm{~km}$ before it joins the Kelani river. On the way Wak oya also receives water from other feeding canals. The two weirs, one at Kalatuwawa and the other across the upper part of Wak oya are $175 \mathrm{~m}$ above the sea level forming two reservoirs which supply water to the city of Colombo.

The Labugama weir, constructed by the British Colonial Government in 1882, is $26.5 \mathrm{~m}$ high and $150 \mathrm{~m}$ long. The greatest depth of the reservoir is $22.5 \mathrm{~m}$. The submerged area is 83 ha while its catchpent area is 1012 ha. The Labugama reservoir is fed by seven feeding canals. The Kalatuwawa weir, which was constructed in 1960, across Kalatuwawa-ela is $30 \mathrm{~m}$ in height and $160 \mathrm{~m}$ in length. The reservoir formed has a submerged area of $195 \mathrm{ha}$. and a catchment area of 1345 ha. Its greatest depth is $20 \mathrm{~m}$. The Kalatuwawa reservoir is fed by 10 main feeding canals.

There is generally no downstream water discharge through the weirs. Therefore just below the weirs the stream becomes very narrow with little water for $1.5 \mathrm{~km}$. However some water is discharged into the stream during the rainy seasons when the reservoirs overfiow through spillways. During the renovation of sand beds of water purification plants some water contaminated with chemicals is added to the stream.

Thirty three stations representing all possible habitats of the main stream, the two reservoirs and the feeding canals of reservoirs were selected and sampled between 8.30 a.m. and 3.30 p.m. once a month from January 1990 to August 1992 (Figure 1). Fishes were sampled using a cast net (radius $2.1 \mathrm{~m}$, mesh size 8 $\mathrm{mm}$ ). The cast net was operated 3-5 times in each station. Fishes were identified according to Deraniyagala ${ }^{13}$ Munro $^{14}$ and Pethiyagoda. ${ }^{15}$ The number of species of 


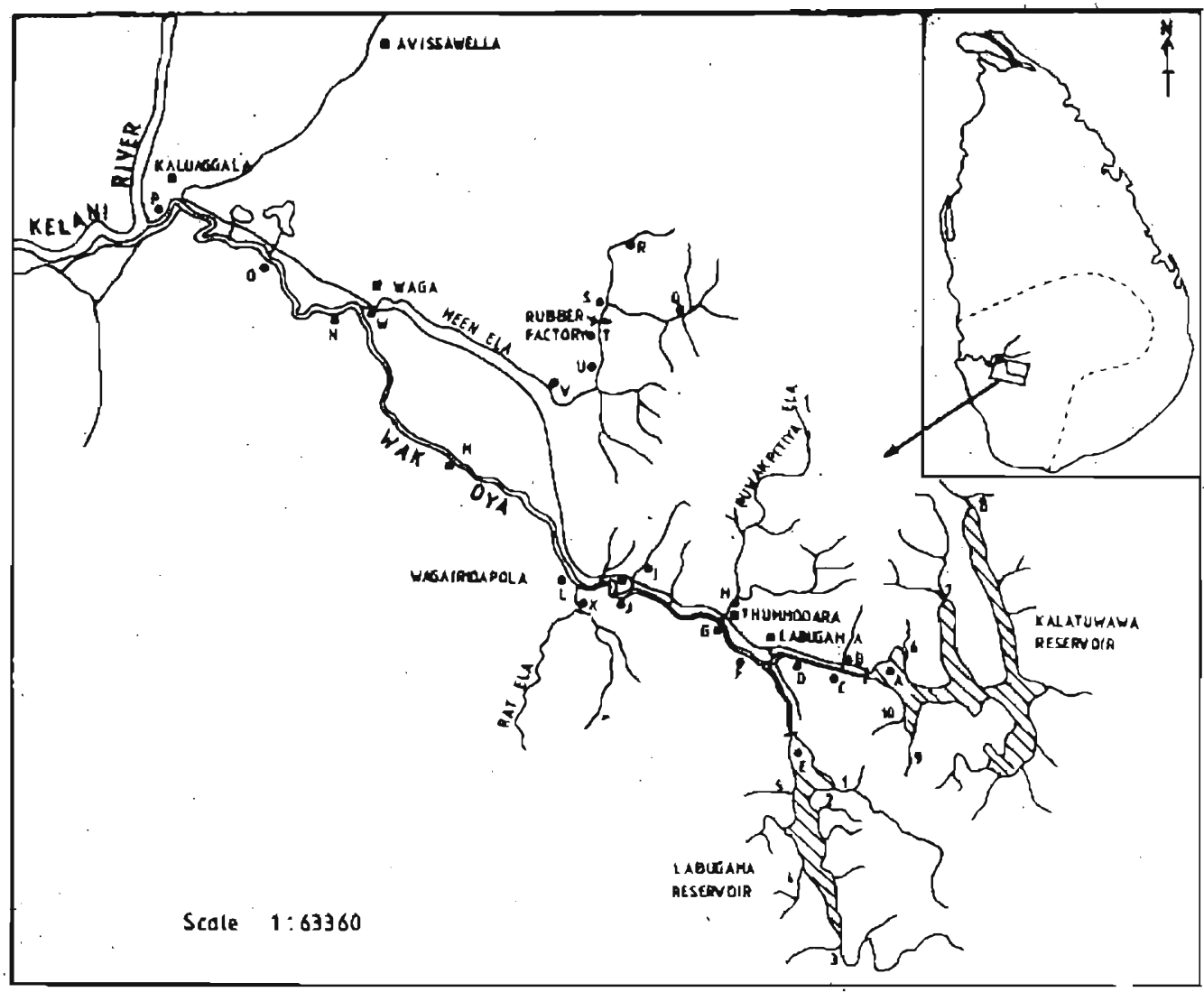

Figure 1: Map of the study area A-W = sampling stations of the stream ond reservolrs. $1.10=$ fceding canals of reservolrs, $A=$ Kolatuwawa reservolr, E=Labugama reservolr. 
fish and their distribution were recorded. The relative abundance of fish was calculated as the number of fish caught per unit operation of the cast net and the species diversity of fish was calculated as the number of species per station. The physico-chemical properties which included, conductivity, temperature, total alkalinity, and the flow velocity of surface water were measured in the field.

The amount of dissolved ions and oxygen was measured titrimetrically or turbidimetrically using the water samples brought to the laboratory. The concentration of sodium and pottasium ions was determined using a Corning 410 type Flame Photometer, while that of sulphates was determined with a CECIL CE 373 type Linear Grating Spectrophotometer. The $\mathrm{pH}$ of the water was measured using a OGAWA osk 14830 digital $\mathrm{pH}$ meter. Dissolved oxygen of water was determined by Winkler's method while that of chloride ions was determined by Harvey's method. The total hardness of water was determined titrimetrically. Rainfall data were obtained from the Water Resources Development Board of Labugama and Kalatuwawa. People of the area were interviewed about the fishery information of reservoirs.

\section{RESULTS}

\section{Horizontal variation of physico-chemical parameters}

Temperature: There was a downstream increase of mean monthly values of surface water temperature of the stream (Fig. 2). The mean of surface water temperature of the feeding canals $\left(22.7-25^{\circ} \mathrm{C}\right)$ was 3 to $5^{\circ} \mathrm{C}$ lower than that of the main stream and reservoirs. The highest surface water temperature was recorded for Kalatuwawa Reservoir $\left(30.2 \pm 2{ }^{\circ} \mathrm{C}\right)$ while the lowest value was recorded for the feeding canal Kapuru ella $\left(22.95 \pm 0.35^{\circ} \mathrm{C}\right)$.

Flow velocity: The flow velocity of water depends upon the strem slope, flow depth and resistance to flow by the stream bed. In the main stream, the slope of upper part was higher than that of other stations and the resistance to flow by stream bed was very low near the river due to the absence of boulders. Therefore the flow velocity of the upper and lower parts of the main stream were higher than that of the middle part (Table 1).

Rainfall: The monthly rainfall of the Labugama and Kalatuwawa in 1990 is shown in the Figure 3 and Figure 5. There were two peaks in the year and the two dry seasons extended from December to February and August to September.

Conductivity: The conductivity, which is a measure of total dissolved ions in water, varied from 30 to 175 micrombo $\mathrm{cm}^{-1}$ among the stations during the period of study. Generally the conductivity of water of mainstream was higher than that of reservoirs and feeding canals (Table 1). The highest mean conductivity was recorded for the stations just below the weirs $\left(112 \pm 45\right.$ micromho $\left.\mathrm{cm}^{-1}\right)$ and rubber factory $(96 \pm 34$ 


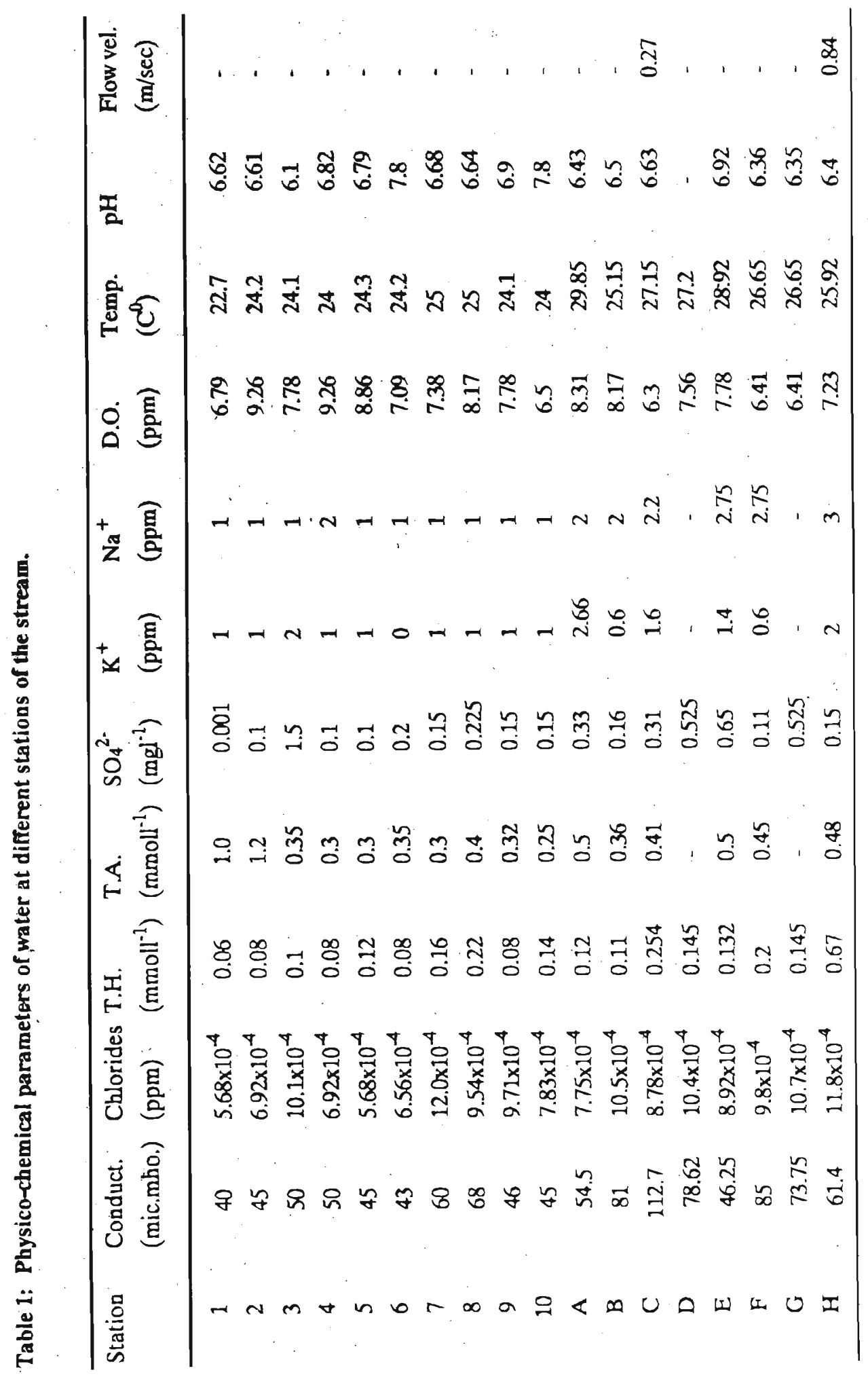




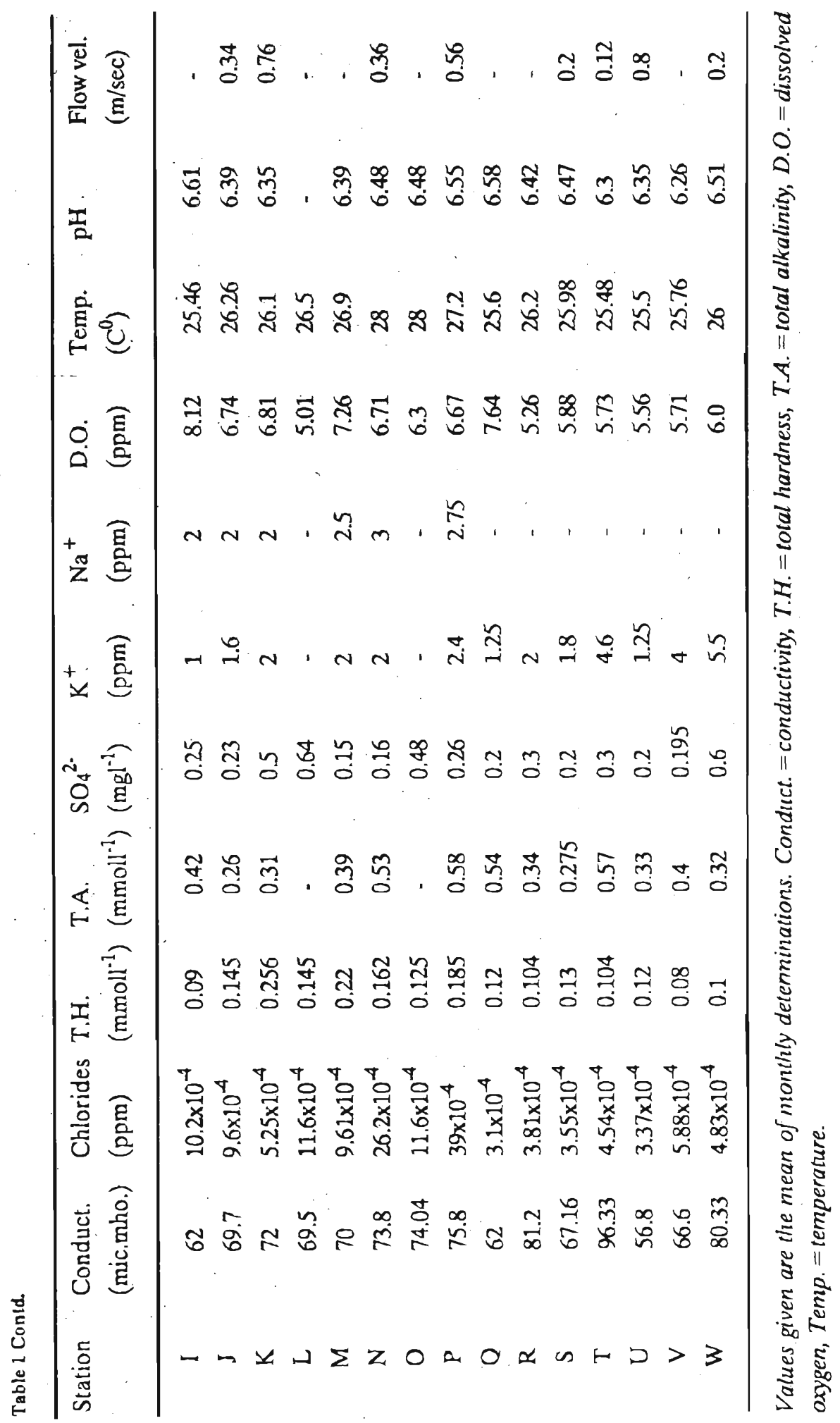




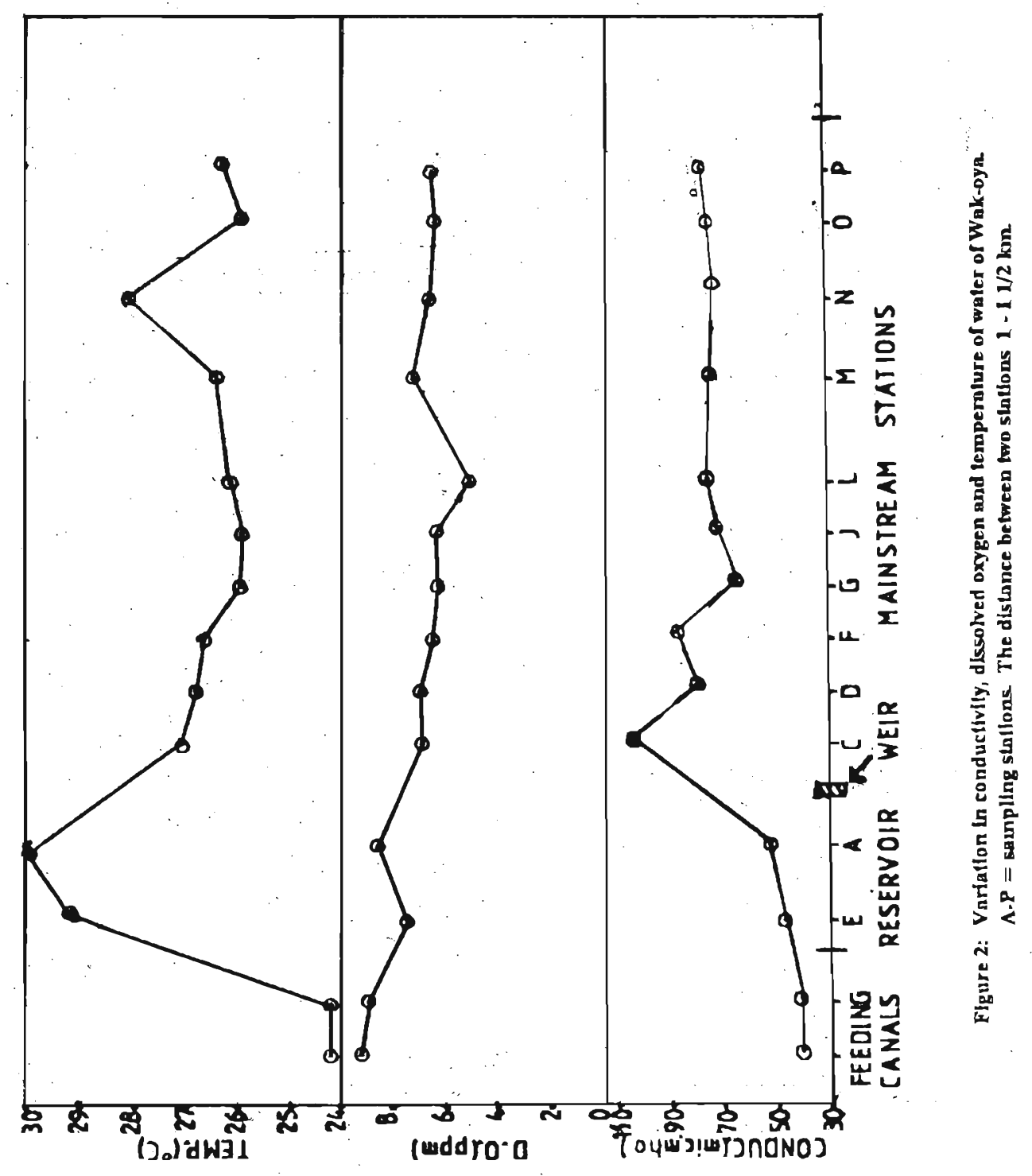




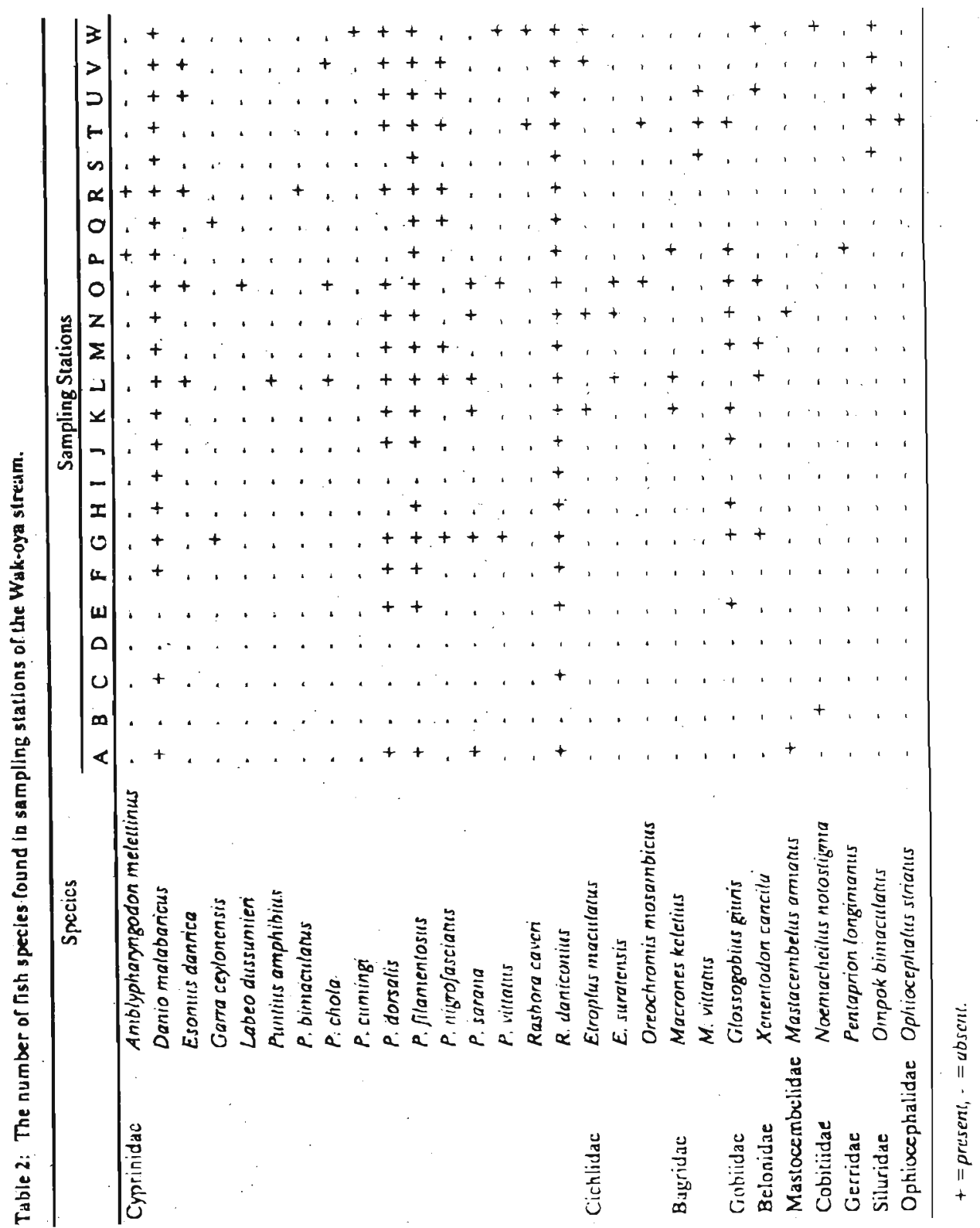


micromho $\mathrm{cm}^{-1}$ ) while the lowest conductivity was recorded for the Labugama Reservoir $\left(40 \pm 6\right.$ micromho $\left.\mathrm{cm}^{-1}\right)$. There was a downstream increase in the monthly mean conductivity of water (Figure 2).

Choloride ions: The mean monthly values of concentrations of chloride ions in water varied from $3.1 \times 10^{-4} \mathrm{ppm}$ to $39 \times 10^{-4} \mathrm{ppm}$ (Table 1). The feeding canals and reservoirs contained lesser amount of chloride ions $\left(3.1 \times 10^{-4}\right.$ to $\left.12.02 \times 10^{-4} \mathrm{ppm}\right)$ than that of mainstream $\left(9.6 \times 10^{-4}\right.$ to $\left.39 \times 10^{-4} \mathrm{ppm}\right)$. There is a downstream increase of chloride ion concentration of the stream. The highest mean monthly concentration value of chloride ions was recorded for the station (Station $p$ ) near the river $\left(39 \times 10^{-4} \mathrm{ppm}\right)$.

$\mathrm{Na}^{+}$and $\mathrm{K}^{+}$ions: The mean monthly values of concentration of $\mathrm{Na}^{+}$and $\mathrm{K}^{+}$ions of water varied from $1 \mathrm{ppm}$ to $5.5 \mathrm{ppm}$ (Table 1). The lowest mean value for the concentration of $\mathrm{K}^{+}$and $\mathrm{Na}^{+}$was recorded for the feeding canals of reservoirs ( $1 \mathrm{ppm}$ ) while the highest value was recorded for the stations below the rubber factory $(5.0 \mathrm{ppm})$. There was a slight downstream increase of mean values of $\mathrm{K}^{+}$and $\mathrm{Na}^{+}$concentrations.

Sulphate ions: The horizontal variation of sulphate ion concentration in water was not very clear. The mean monthly values varied form $0.001 \mathrm{mg} \mathrm{l}^{-1}$ to $1.5 \mathrm{mg}^{-1}$ (Table 1). The highest mean value was recorded in the feeding canal no. 3 , which is the upper part of the Wak oya stream above the Labugama reservoir. The lowest value was recorded in the feeding canal no. 1 Kapuru ella.

Total alkalinity: Total alkalinity is a measure of carbonate and bicarbonate ions in water. There was a downstream increase of mean monthly total alkalinity of water (Table 1). The highest mean value for the monthly total alkalinity was recorded for the feeding canal no. $4 \mathrm{Mul}$-dola $\left(1.2 \mathrm{mmol}^{-1}\right)$ of the Labugama reservoir while the lowest value was recorded for the station $\mathrm{J}\left(0.26 \mathrm{mmol} \mathrm{l}^{-1}\right)$ of the mainstream.

Total Hardness: The total hardness which is a measure of calcium and magnesium ions in water shows a irregular horizontal change. The highest mean value was recorded for the feeding canal Rat-ela $\left(0.67 \mathrm{mmol} \mathrm{l}^{-1}\right)$ while the lowest mean value was recorded for the feeding canal no. 1 Kapuru ella $\left(0.06 \mathrm{mmol}^{-1}\right)$ of Labugama reservoir.

Dissolved oxygen: Downstream decrease of dissolved oxygen in water was clearly evident in Wak oya (Figure 2). The highest mean value was recorded for feeding canals of the reservoirs $(8.5 \pm 0.4 \mathrm{ppm})$ while the lowest mean value was recorded for the stations near the rubber factory $(5.78 \pm 0.6 \mathrm{ppm})$.

pH value: The mean pH value was between 6.21 and 7.8. The highest value was recorded for feeding canal No. 6 of Kalatuwawa Reservoir (7.14 \pm 0.93$)$, while the lowest value was recorded for the station below the rubber factory $(\mathrm{pH}=6.3 \pm 0.2)$. 


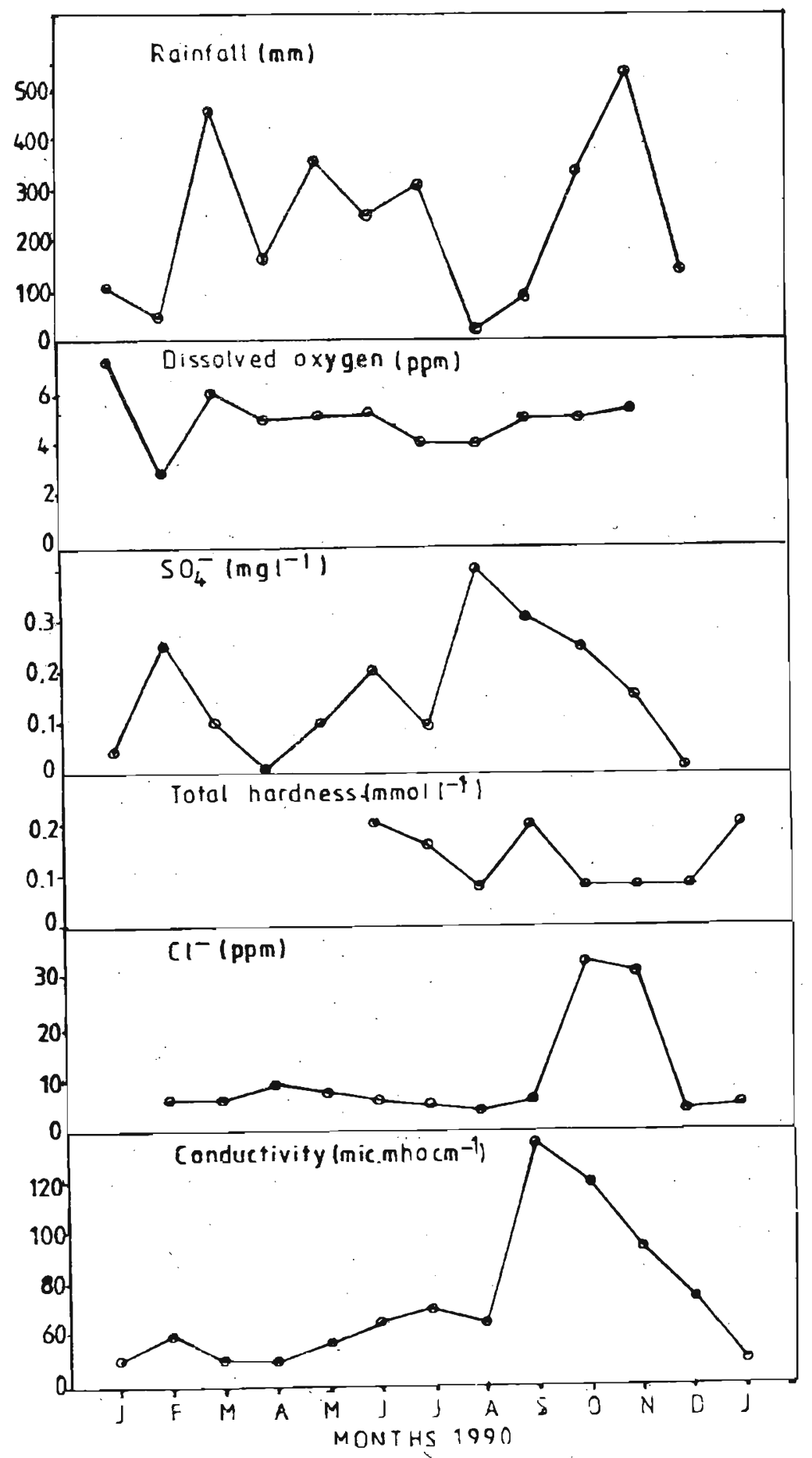

Figure 3: Seasonal variation of conductivity, chloride tons, total hardness, sulphate lons and dissolved oxygen in Wak-oya in 1990. 


\section{Seasonal variation of physico-chemical parameters}

The seasonal variation in weather in the Wet Zone of Sri Lanka is rainfall. The variation of monthly values of conductivity, chloride ion concentration, total hardness, sulphate ion concentration and dissolved oxygen with the monthly rainfall for the station $\mathrm{G}$ is shown in Figure 3. Conductivity, chloride ion concentration and dissolved oxygen of water showed a positive correlation while total hardness and sulphate ion concentration showed a negative correlation with monthly rainfall. This relationship was also observed at three other stations ( $C, L \& O$ ) representing the upper, middle and lower parts of the stream.

Horizontal variation of composition, distribution, diversity and relative abundance of fish

Composition: Wak oya supports 28 species of fish of which 16 were cyprinids, 3 were cichlids, two were from the family Bagridae, and one each from the families: Siluridae, Ophiocephalidae, Gobidae, Belonidae, Mastocembelidae, Cobitidae and Gerridae (Table 2). Of these 28 species $P$. nigrofasciatus, $P$. cumingi (Gunther), Garra ceylonensis (Bleeker) and Noemacheilus notostigma (Bleeker) are endangered and endemic to Sri Lanka.

The downstream variation of the percentage frequencies of the three main rypes of fishes the cyprinids, the cichlids and other species are shown in Table 3. A downstream decrease in cyprinids and a downstream increase in cichlids and other species were observed. The cyprinids contribute a major part to the composition of fish in reservoirs and upper and middle parts of the stream while the cichlids and other species contribute a major part to the composition of fish in the lower part near the river. The downstream variation of percentage frequencies of individual species were shown in the.Table 4. A downstream decrease in cyprinids and increase in cichlids and other species were observed.

Table 3: Variation in fish types in 1990.

\begin{tabular}{ccccc}
\hline Station & Cyprinids \% & Cichlids \% & Other spp. \% & Total no. of fish \\
\hline Resevoirs & 99.80 & 0 & 0.20 & 503 \\
D & 100.00 & 0 & 0 & 8 \\
G & 99.00 & 0 & 1 & 78 \\
L & 99.15 & 0.28 & 0.57 & 1196 \\
O & 88.10 & 2.40 & 9.50 & 194 \\
P & 48.25 & 0 & 51.75 & 31 \\
\hline
\end{tabular}

Values are mean monthly percentages. $D=$ upper part, $G \& L=$ middle part, $O \& P=1$ wer part. 


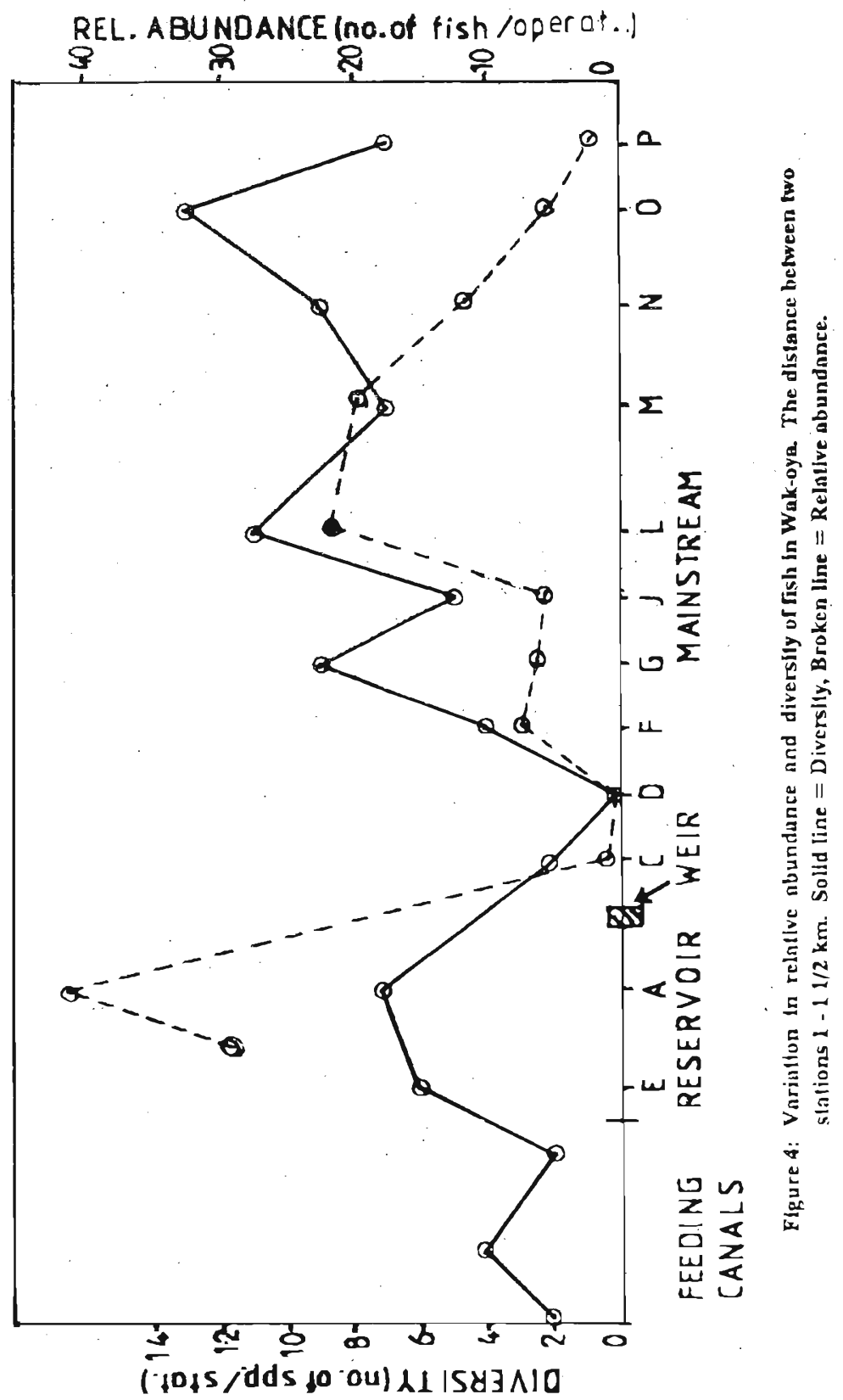


Distribution: The three species, Puntius filamentosus (Valenciennes), Danio malabaricus (McClelland) and Rasbora daniconius (Hamilton-Buchanan) are evenly distributed in the stream including feeding canals, reservoirs and the mainstream and they form a major part of the fish population. Therefore, they are the dominant and best adapted species in the stream. The two species Garra ceylonensis and Noemacheleilus notostigma were confined mainiy to the feeding canals of reservoirs with rapids and pools, stream bed with boulders and water with higher oxygen concentraion and low temperature. $P$. nigrofasciatus and $P$. bimaculatus (Bleeker) inhabited the upper parts of feeding canals (Heen-ela, Puwakpitiya ela and Rat ela) and mainstream with shade and fields of Aponogeton crispum for shelter. Occasionally these fish were found in the stations of the mainstream where feeding canals open to the mainstream. The species such as $P$. chola (Hamilton-Buchanan) and $P$ vittatus (Day) which are common in marshes were occasionally found in the middle and lower parts of the mainstream. P. cumingi, which is very rare in this stream was found in the lower part of the feeding canal viz. Heen ela where the water is very clear and the bottom is sandy. P. sarana (Hamilion-Buchanan), $P$. dorsalis (Jordon) and Xenentodon cancila (Hamilton-Buchanan) inhabited the middle and lower parts of the stream. Tor khudree (Gunther) which inhabits the reservoirs was not found in the stream below the weirs. The other cyprinids namely Labeo dussumieri (Valenciennes), Esomus danrica (Valnciennes), Rasbora caveri (Brittan) and Amblypharyngodon melettinus (Valenciennes) were occasionally found in lower parts of the stream. The three Cichlids, Etroplus maculatus (Bloch), E. suratensis (Bloch) and Oreochromis mosambicus were confined to the lower part of the mainstream and the feeding canal Heen-ela. The species namely Glossogobius ginis (Hamilton-Buchanan), Macrones keletius(Valenciennes) and the brackish water species Pentaprion longimanus (Cantor) were limited to the part of the stream near the river which flooded by river water during the peaks of rainy seasons. Very rarely Glossogobius giurus and Mastacembelus armatus (Lacepede) were also found in reservoirs. There were no fish at all for $11 / 2 \mathrm{~km}$ below the Kalatuwawa weir. The species Macrones vittatus, Ompok bimaculatus (Bloch) and Ophiocephalus striatus (Bloch) were found in the feeding canal Heen ela. These fist were caught during the sampling at night.

Diversity: There is a downstream increase of diversity of fish measured as the number of species per station (Fig. 4). In feeding canals of reservoirs the diversity of fish varied from 2 to 5 while in reservoirs it varied form 6 to 7 . In the stations of the main. stream, the diversity of species varied from 2 to 13 . The maximum number of species was found in the station 0 in the lower third of the stream. However, when the stream reaches the river the diversity reduced again. In the stations near the weirs $(C \& D)$ the diversity was very low (0 to 2$)$.

Relative Abundance: The horizontal variation of mean relative abundance of fish measured as the number of fish per unit operation of the cast aet is shown in Figure 4. The highest relative abundance was recorded for the two reservoirs 
$(29.5 \pm 18.7$ and $43.3 \pm 16.9$ fish/unit operation) while the lowest relative abundance was recorded for the stations near the weirs (0-0.14 \pm 0.26 fish/unit operation). Below the weirs there is a downstream increase of relative abundance (Fig. 4). However, when the stream reaches the river the relative abundance of fish decreased again.

Table 4: Variation in fish species in 1990.

\begin{tabular}{|c|c|c|c|c|c|c|}
\hline \multirow[t]{2}{*}{ Species } & \multicolumn{6}{|c|}{ stations } \\
\hline & $\mathbf{A}$ & D & $G$ & $\mathrm{~L}$ & 0 & $P$ \\
\hline$\cdot$ & $\%$ & $\%$ & $\%$ & $\%$ & $\%$ & $\%$ \\
\hline P. filamentosus & 59.8 & 0 & 30 & 30 & 14.2 & 12.5 \\
\hline P. dorsalis & 0 & 0 & 5.8 & 19 & 2.6 & - \\
\hline P. sarana & 0 & 0 & 0.14 & 0.63 & 2.5 & 8 \\
\hline P. nigrofasciatus & 0 & 0 & 0.12 & 0.29 & 0 & 0 \\
\hline P. bimaculatus & 0 & 0 & 0 & 0 & 0 & 0 \\
\hline P. amphibius & 0 & 0 & 0 & 0.18 & 0 & 0 \\
\hline P. cumingi & 0 & 0 & 0 & 0 & 0 & 0 \\
\hline$P$. vittatus & 0 & 0 & 2 & 0 & 0.78 & 0 \\
\hline P. chola & 0 & 0 & 0 & 0.85 & 3 & 0 \\
\hline D. malabaricus & 35 & 50 & 52 & 30 & 60.8 & 25.5 \\
\hline R. daniconius & 5 & 50 & 9 & 18 & 3.4 & 0 \\
\hline R. caveri & 0 & 0 & 0 & 0 & 0 & 0 \\
\hline Gana ceylonensis & 0 & 0 & 0.24 & 0 & 0 & 0 \\
\hline E. danrica & 0 & 0 & 0 & 0.1 & 0.5 & 0 \\
\hline A. melatinus & 0 & 0 & 0 & 0 & 0 & 2.25 \\
\hline L. dussumien & 0 & 0 & 0 & 0 & 1.8 & 0 \\
\hline Tor khudree & + & 0 & 0 & 0 & 0 & 0 \\
\hline E. maculatu & 0 & 0 & 0 & 0 & 0 & 0 \\
\hline E. suratensiss & 0 & 0 & 0 & 0.3 & 0.82 & 0 \\
\hline O. mosambicus & 0 & 0 & 0 & 0 & 2.2 & 0 \\
\hline$X$. cancila & 0 & 0 & 0.83 & 0.22 & 1.3 & 0 \\
\hline Macrones keletius & 0 & 0 & 0 & 0.4 & 0 & 9.25 \\
\hline Mastocembailus amatus & 0.2 & 0 & 0 & 0 & 0 & 0 \\
\hline G. giuris & 0.1 & 0 & 0.8 & 0 & 6.86 & 40.75 \\
\hline N. notostigma & 0 & 0 & 0 & 0 & 0 & 0 \\
\hline P. logimanus & 0 & 0 & 0 & 0 & 0 & 1.75 \\
\hline Total number of fish & 503 & 8 & 78 & 1196 & 194 & 31 \\
\hline
\end{tabular}

Values are mean monthly percentages. $A=$ reservoir, $D=$ upper part, $G \& L=$ middle part, $O \& P=$ lower part. 


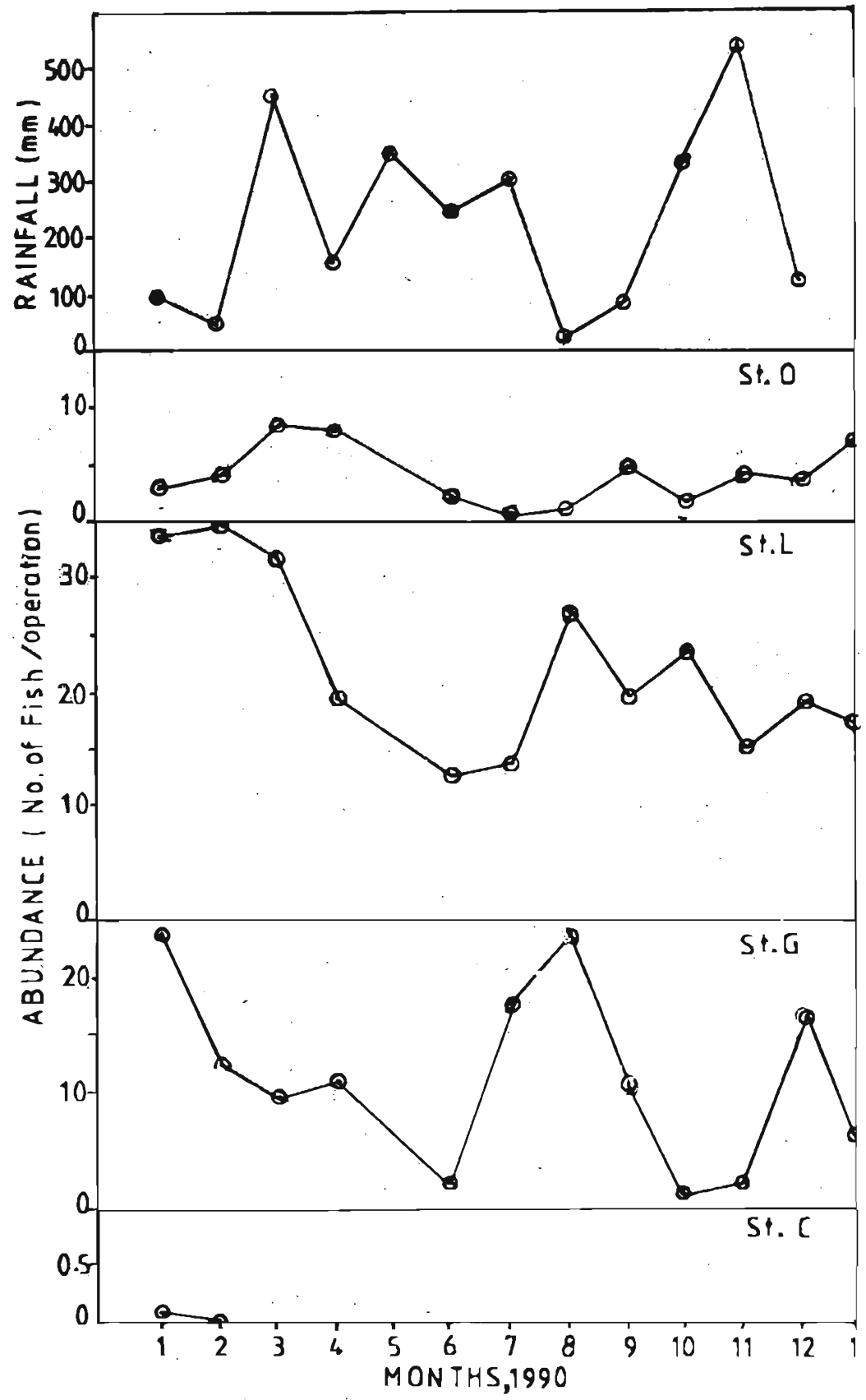

Figure 5: Seasonal variation in relative abundance of nsh In 1990. The four dinterent slations represent the three parts of the stream Wak-oya. St.C=upper part, St.G\&L=middle part, SLO=lower part. 


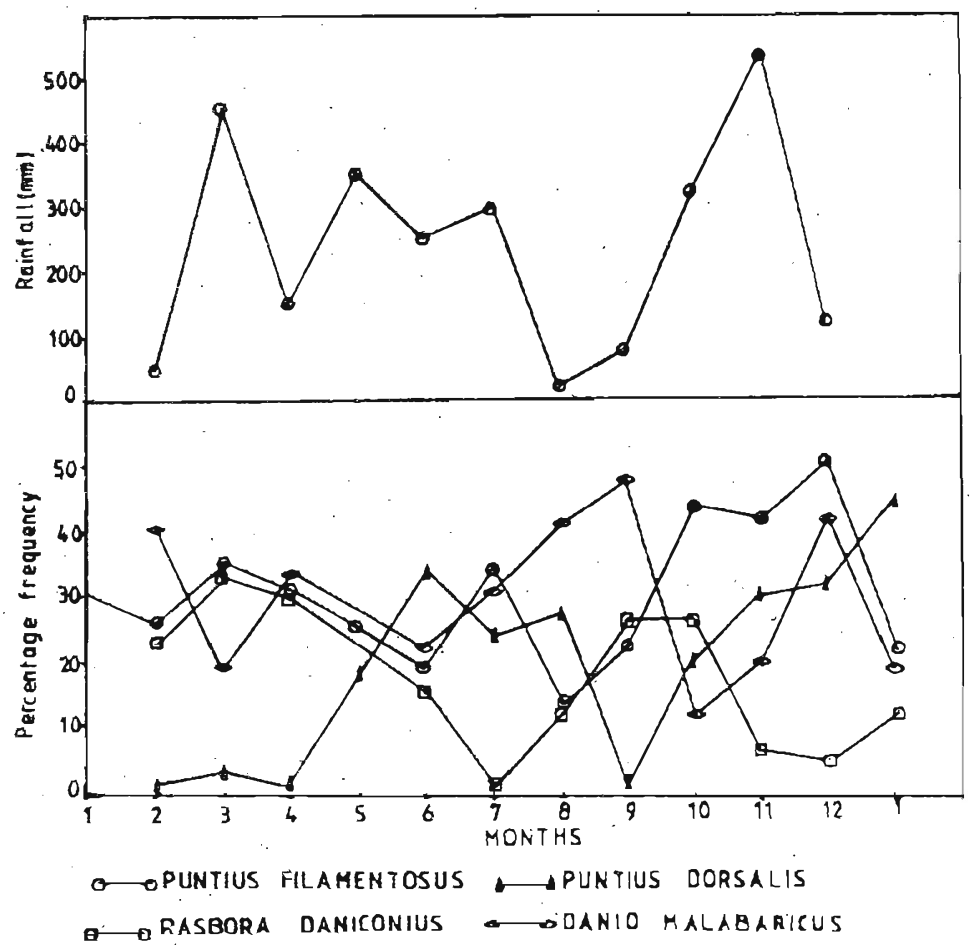

Flgure 6: Segsonal variation in frequencies of four dominant fish specles, $P$. Nlamentosus, $P$. dorsalis $R$. daniconius and $D$. malabaricus at station $G$ in 1990.

\section{Seasonal variation of relative abundance and diversity of fish}

Relative abundance: The seasonal variation of relative abundance of fish in sampling Stations $C, G, L$ and $O$ representing the whole length of mainstream is shown in Figure 5. In the station $C$ which is near the weir, there were no fish at all after March 1990. The seasonal variation of relative abundance of fish in stations $G$ and $L$ which represent the middle part of the stream shows a similar pattern of variation. In these two stations the abundance of fish negatively correlates with rainfall and in the month of January, February and August where the monthly rainfall was very low the abundance of fish was higher than that of other months. In the station $O$, which flooded with river water during the peaks of rainy seasons, the abundance of fish was very low and the abundance of fish show a positive relationship with the monthly rainfall.

The seasonal variation of the abundance of the most common four species, $P$. filamentosus, $P$. dorsalis, $D$. malabaricus and $R$. daniconius of the station $\mathrm{G}$ is shown in Figure 6. It shows that the population of these species varied with the monthly rainfall. 


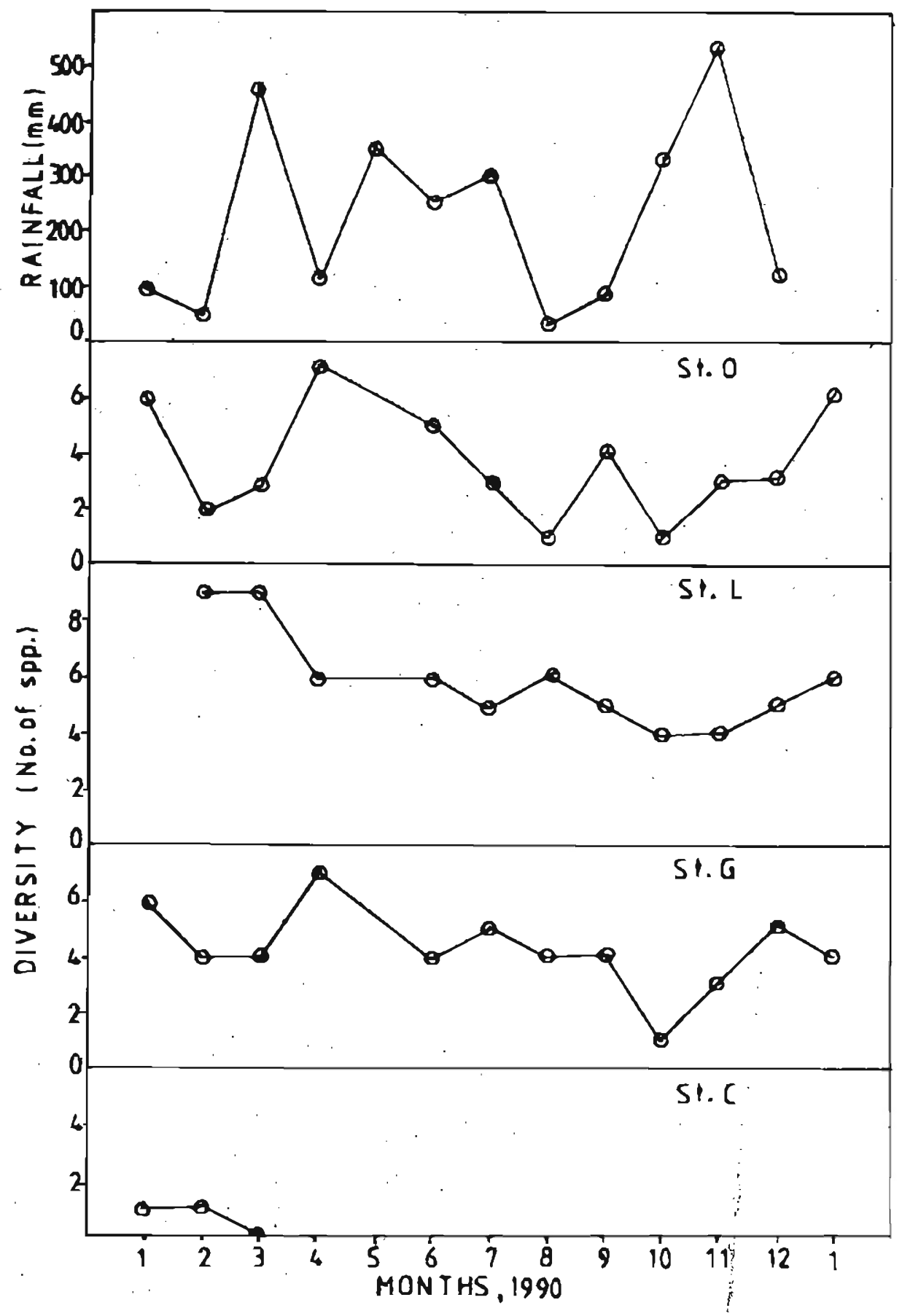

Figure 7: Seasonal vanation in fish diversily In 1990. The four dimerent siallons represent the upper part middle part and the lower part of the stream Wak-aya SLC = upper port SI.G\&L = middle parL SLO $x$ lower part 
Diversity: The seasonal variation of diversity of fish in the Stations $C, G, L$ and $O$ representing the upper, middle and lower parts of the mainstream is shown in Figure 7. It shows that after peaks of rainfall the diversity of fish increased.

\section{DISCUSSION}

The native fish fauna of the Tennessee river system have been affected by dams, introduced species, toxic spills, mining and agriculture. ${ }^{1}$ Accordirig to the studies of Tennessee river system, some riverine fish species did not survive in the reservoirs and after the inundation the species richness and relative abundance of fish drastically changed with a shift of composition of fish. The reservoir of the Clinch River of U.S. supported 17 families and 65 species of native fish before its impoundment in 1936. Fish sampling subsequent to the impoundment indicated the loss of four families and several genera of Cyprinidae. ${ }^{1}$

The reduction of species richness in reservoirs is due to the habitat changes of that part in the stream. The removal of free flow of water, the increase of depth of water, the removal of shady water plants due to inundation, the increase of surface water temperature, the accumulation of dissolved ions and silting are the main habitat changes that affect the fish fauna. Deposition of silt on spawning grounds prevent the hatching of eggs of fish. ${ }^{16}$

With the construction of the two weirs across Wak oya stream, the upper part of Kalatuwawa ela and its feeding canales and the upper part of Wak oya were inundated. Most of the free flowing parts of the stream with riffle habitats were eliminated. The present study shows a reduction of the species richness of inundated part of the stream compared to the free flowing part of the stream. The part of the stream below the weirs supports 26 species while the inundated part which is a large water body supports only 6 species. This proves the effect of above habitat changes.

The endemic and endangered species such as $P$. nigrofasciatus, $P$. cumingi, Garra ceylonensis, and Noemacheilus notostigma are found in the feeding canals of reservoirs but not in reservoirs. It shows that these species were eliminated from the inundated part. However, due to the lack of preimpoundment data it is very difficult to conclude the number of species eliminated from the inundated part of the stream.

The three cyprinids, Danio malabaricus, Rasbora daniconius and Puntius filamentosus were found in all habitats including the feeding canals, reservoirs and the main stream. It shows that these species were adapted to live in reservoirs. Tor khudree and Mastacembelus armatus were also adapted to the reservoirs.

Although the species richness is low in reservoirs the relative abundance of fish is higher than that of feeding canals and the mainstream. This may be due to the increase of habitat area with higher amount of phytoplankton and zooplankton. The 
accumulation of dissolved ions and the calm water of reservoirs may be the reasons for the increase of plankton. This affects the food supply of fish of reservoirs and hence the abundance of fish.

The dams affect not only the fish fauna of inundated part but also the fish fauna of the lower part of the streams and rivers below the dams. In the South Folk Holston River of the U.S., preimpounding sampling yielded 43 species, where 17 species were collected in the tailwaters after the operation of the dam. Thirty two species were collected in the Watauga River of the U.S. before the construction of Wilber dam, compared to only 13 species in the tailwaters after the impoundment. ${ }^{1}$ Elimination of fish species in tailwaters was due to the stressful conditions created for fish by the altered flow regime and cold water discharges with reduced oxygen concentration. ${ }^{1}$ There is no hydro-electric power porduction at Kalatuwawa and Labugama and hence there is no discharge of water from the resovoirs. The down flow regine of this stream is therefore severely disturbed. It is evident by the dried portion of the stream below the Kalatuwawa weir and the narrowness of the mainstream below the weirs. Therefore the absence of fish for about $2 \mathrm{~km}$ of the stream below the weirs is due to the altered flow regime of the stream. Although there was no fish just below the weirs, there was a downstream recovering of species richness and relative abundance of fish. This was due to the reestablishment of the stream by feeding canals below the weirs.

Generally most of the cyprinids in streams migrate to feeding canals in the rainy seasons for spawning. 5 This was confirmed by the observation of upward migration of $P$. sarana, $P$. filamentosus, $P$. bimaculatus, $D$. malabaricus and $R$. daniconius over the anicuts of Pussali oya. The weirs across Wak oya completely cut off the lower part of the stream from the upper part which contained large number of feeding canals. Therefore the two weirs prevent the upward migraton of fish for spawning. This would have significant impact on migratory species that utilized the feeding canals above the weirs. The seasonal changes of diversity and abundance of fish of the main stream may be due upward migration of some fish species during the rainy season.

While deforestation and urbanization have been major causes of the decline in number of native fishes, their impact has been greatly increased by gem mining activities, which causes streams already denuded of cover and shade to become turbid and silty. ${ }^{4}$ It is common for the people of Waga-Kalatuwawa area to excavate the Wak oya stream bed for gems in the dry season. This causes the formation of stagnant pools, increase dissolved ions and turbidity of water, which are unfavourable for stream fish. The large scale removal of boulders from the stream for the decoration of gardens of urban areas is the latest hazard to the stream fish fauna. It removes the insect larvae on boulders which is a main food source of some fish. 
There are toxic spills from the rubber factories and water purification plants. During the renovation of sand beds of water purification plants, water contaminated with alum, $\mathrm{Ca}(\mathrm{OH})_{2}$ and free chlorine is released to the stream. The effect of this contamination was evident by the absence of fish in the part of the stream near the weirs. The effect of release of waste water of rubber factory was clearly evident by the absence of fish in the feeding canal, Heen ela near the factory during the dry season. Normally in dry seasons the water below the factory turns milky and fish are rarely caught. Bathing is not possibale in this part of the stream due to the acidity.

The downstream increase of conductivity, dissolved ions, temperature, diversity and abundance of fish, and the downstream decrease of dissolved oxygen is a general pattern of streams. ${ }^{17}$ However, the present study shows that there is a abnormal increase of conductivity and dissolved ions and decrease of $\mathrm{pH}$ value in water just below the weirs and rubber factory. This was due to the release of chemically contaminated water to the stream. Besides these abnormalities the variation of the physico-chemical parameters shows the general pattern of streams. The downstream increase of temperature tend to decrease the dissolved oxygen in water. The horizontal distribution pattern of fish in part may be a reflection of the availability of oxygen, food, dissolved ions, space and the velocity of water. Increasing dissolved ions along the lengh of downstream influence the distribution of certain fish species which require particular levels of inorganic ions or specific food items. The increase of habitat area, depth and velocity of water and abundance of food items may be another fact to the downstream increase of abundance and diversity of fish.

The results of present study indicate that it is valuable to conduct pre-and post-impoundment surveys of all streams and rivers of Sri Lanka to evaluate the richness of fish and other aquatic fauna. It is also important to make a minimum water discharge in impounded streams and rivers to maintain the flow regime and to make fish ladders for the migration of fish.

\section{Acknowledgement}

I am grateful to Dr. J. Jinadasa and Dr. Ajantha De Alwis of the Department of Zoology for constructive criticisms and to Indunil Divigalpitaya and Manjula Mapatuna for help with the field work.

\section{References}

1. Neves R.J. \& Angermeier P.L. (1990). Habitat alteration and its effects on native fish fauna of tennessee river system east central U.S.A. Joumal of Fish Biology 37:45-52.

2. Kapasa C.K. \& Cowx I.G. (1991). Post impoundment changes in the fish fauna of lake Itezhi-tezhi Zambia. Joumal of Fish Biology 39: 783-793. 
3. Crisp.D.T. \& Mann R.H.K. (1991). Effects of impoundment on populations of bullhead Cottus gobio (L). and Phoxinus phoxinus (L) in the basin of Cow Green Reservoir, Joumal of Fish Biology 38: 731-740.

4. Senanayake F.R. \& Moyle P.B. (1982). Conservation of freshwater fishes of Sri Lanka, Biological Conservation 22: 181-195.

5. TAMS (1989). Kalu Ganga multipurpose project, prefeasibility study, Supporting report of Environmental studies part 1 and 2, Initial Environmental Examination (IEE).

6. Daniel D.J., Costa H.H. \& Wijayaratne, M.J.S. (1988). The hydrobiology and fish production potential of major freshwater reservoirs in Hambantota district, Sri Lanka. Journal of Inland Fisheries 4: 95-121.6.

7. Siriwardana P.P.G.N. \& Tissa R.P.K. (1988). Seasonal and diurnal changes in some physico-chemical parameters of Bolgoda lake. Joumal of Inland Fisheries 4: 69-93.

8. Piyasiri S. \& Jayakody J.K.U. (1991). Ecology of zooplankton in Victoria Reservoir, Sri Lanka I. Composition and population structure of the zooplankton. Verhandlungen International. Verein. Limnologie 24: 1430-1435.

9. Piyasiri S. (1991). Limnology Project at Mahaweli Reservoirs I. Some physicochemical properties of Kotmale, Victoria and Randenigala Reservoirs. Vidyodaya Joumal of Science 3(1): 44-61.

10. Costa H.H. \& Fernando E.C.M. (1967). The food and feeding relationships of the common meso and macrofauna in the Maha-oya, a small mountain stream at Peradeniya, Ceylon. Ceylon Joumal of Science. 7:74-90.

11. Kortmulder K. (1987). Ecology and behaviour in tropical freshwater fish communities. Archive fur Hydrobiology. Beih Ergebnisse der Limnologie. 28: 503-513.

12. Schut J.A., Silva De S.S. \& Kortmulder K. (1984). Habitat association and competition of Eight Barbus (Puntius) species indigenous to Sri Lanka. Netherland Jourrial of Zoology 34: 159-181.

13. Deraniyagala P.E.P. (1952). A coloured atlas of some vertebrates from Ceylon, I Pisces, Ceylon National Museum Publication. Colombo i-x, 1-49.

14. Munro I.S.R. (1955). The marine and fresh water fishes of Ceylon, pp. 1-351. Department of External Affairs, Canberra.

15. Pethiyagoda R. (1990). Freshwater fishes of Sri Lanka. pp.1-362. Wildlife Heritage Trust of Sri Lanka, Colombo. 
16. Evans D. (1981). Threatenned freshwater fish of Sri Lanka, pp. 1-28. IUCN Conservation Monitoring Centre, Cambridge, U.K.

17. Townsend C.R. (1980). The ecology of streams and rivers. Studies in biology. No. 122. Edward Arnold. 